\title{
Coring the sedimentary expression of the early Toarcian Oceanic Anoxic Event: new stratigraphic records from the Tethys Ocean
}

\author{
Elisabetta Erba, Gabriele Gambacorta, Stefano Visentin, Liyenne Cavalheiro, Dario Reolon, \\ Giulia Faucher, and Matteo Pegoraro \\ Dipartimento di Science della Terra, Università degli Studi di Milano, Milano, Italy \\ Correspondence: Elisabetta Erba (elisabetta.erba@unimi.it)
}

Received: 14 June 2019 - Revised: 2 September 2019 - Accepted: 4 September 2019 - Published: 2 December 2019

\begin{abstract}
The Toarcian Oceanic Anoxic Event (T-OAE) interval was cored at Colle di Sogno and Gajum in the Lombardy Basin (Southern Alps, northern Italy). The Sogno and Gajum cores recovered 26.83 and 31.18 stratigraphic metres, respectively, of pelagic sediments consisting of marly limestones, marlstone, marly claystone, and black shale. Drilling at both sites resulted in $100 \%$ recovery of unweathered material. The pelagic succession comprises a relatively expanded black shale interval of $4.98 \mathrm{~m}$ in the Sogno core and $15.35 \mathrm{~m}$ in the Gajum core, with lower and upper boundaries without evidence of hiatuses. The Sogno and Gajum cores can be considered reference sections for the pelagic lower Toarcian interval of the western Tethys and will provide high-resolution micropaleontological, inorganic and organic geochemical, isotopic multiproxy data. Integrated stratigraphy and cyclostratigraphy are predicted to result in estimates of durations and rates to model the ecosystem resilience to the extreme perturbations of the T-OAE and gain a better understanding of current global changes and help provide better projections of future scenarios.
\end{abstract}

\section{Introduction}

The emergence of climate change as a crucial issue for society has urged the understanding of the future state of the planet within the context of increasing carbon dioxide concentrations. The ocean is the oldest ecosystem and the largest on Earth by volume and best records global changes in climate and atmospheric composition. Marine ecosystems are inextricably involved in the physical, chemical, biological processes of global change. In the near future, the ocean's uptake of $\mathrm{CO}_{2}$ is expected to rapidly decline because of surface water warming, decreasing $\mathrm{pH}$ (acidification), increased vertical stratification, and slowed thermohaline circulation (Solomon et al., 2009). Consequently, a very rapid "in and out" from icehouse to greenhouse state - and vice versa urges comprehension of positive and negative feedbacks on the biosphere.

Understanding of the Earth system at timescales longer than human observations has became imperative, because anthropogenic activities are likely to increase by orders of mag- nitude the rates of climatic change that usually result from natural processes. The Earth's ecosystems, thus, should be scrutinized on the medium- and long-term scales using geological records of past extreme environmental disturbances that exemplify varied tempos and modes of resilience, occasionally reaching tipping points that triggered permanent modifications.

The Toarcian Oceanic Anoxic Event (T-OAE) is the oldest Mesozoic case of global anoxia with widespread deposition of organic matter-rich sediments in a variety of depositional settings from continental to shallow- and deepmarine (Jenkyns, 1985, 1988, 2010). Available evidence suggests that at $\sim 183 \mathrm{Ma}$ the atmosphere and oceans experienced high $\mathrm{CO}_{2}$, possibly due to the degassing of lava fields in the Karoo-Ferrar large igneous province and/or from dissociation and oxidation of methane hydrates in continentalmargin sediments (Jenkyns, 2010) and/or terrestrial environments (Them et al., 2017). High atmospheric carbon dioxide possibly initiated greenhouse conditions that accelerated 
weathering and the hydrological cycle, increasing nutrient recycling into the oceans.

Although the original definition of the T-OAE was based on the presence of a lithostratigraphic marker (Jenkyns, 1985), the development of chemostratigraphy demonstrated that the T-OAE is associated with a negative $\mathrm{C}$ isotopic anomaly documented in marine carbonates and organic matter as well as in terrestrial organic matter including fossil wood and specific organic compounds (Jenkyns and Clayton, 1986; Hesselbo et al., 2000, 2007; Schouten et al., 2000; Jenkyns et al., 2002; Emmanuel et al., 2006; Van Breugel et al., 2006; Al-Suwaidi et al., 2010; Caruthers et al., 2011; Izumi et al., 2012; Kafousia et al., 2014; Reolid, 2014; Xu et al., 2017; Them et al., 2017; Fantasia et al., 2018). As shown by Fantasia et al. (2018), such a negative $\mathrm{C}$ isotopic anomaly might have resulted from volcanogenic $\mathrm{CO}_{2}$, thermogenic methane associated with metamorphism, and dissociation of marine or terrestrial clathrates.

The T-OAE is further marked by an Os anomaly (Cohen et al., 2004; Percival et al., 2016; Them et al., 2017), biocalcification crisis (Erba, 2004; Mattioli et al., 2004; Casellato and Erba, 2015; Erba et al., 2019), increased primary productivity (Jenkyns, 2010; Erba, 2004), and ocean acidification (Erba, 2004; Trecalli et al., 2012; Casellato and Erba, 2015; Posenato et al., 2018), which occurred during an exceptional warming phase (Dera et al., 2011; Korte and Hesselbo, 2011; Gómez et al., 2016) and a major transgression (e.g. Haq et al., 1987; Hardenbol et al., 1998).

Jurassic pelagic successions in the Southern Alps have been extensively investigated for stratigraphy, sedimentology, paleontology, and geochemistry (Bernoulli and Jenkyns, 2009; Erba et al., 2019). In particular, multi- and interdisciplinary studies have demonstrated that the Jurassic pelagic successions of the Lombardy Basin represent "type-sections" of the Tethyan southern margin (Gaetani, 2010). Indeed, the Lombardy Basin is part of the relatively undeformed portion of Adria interpreted as an African "promontory" or as a microplate (Fig. 1). In the latest Triassic-earliest Jurassic a rifting phase caused the breakup of carbonate platforms into a series of "horst and graben" that exerted a physiographic control on sediment type and distribution for most of the Jurassic (Bernoulli and Jenkyns, 1974, 2009; Bosence et al., 2009; Santantonio and Carminati, 2011). As a consequence, sedimentation was differentiated with the deposition of thick complete pelagic successions in the deeper zones, while sedimentation was typically condensed and incomplete on the structural highs.

During the Jurassic the Lombardy Basin was globally a deep area between the Lugano High to the west and the Trento Plateau to the east (Fig. 1). However, the latest Triassic-earliest Jurassic rifting disentangled a number of troughs and paleohighs that are as follows, from west to east: Monte Nudo Trough, Lugano High, Generoso Trough, Corni di Canzo High, Albenza Plateau, Monte Cavallo High, Sebino Trough, Botticino High (Gaetani, 1975, 2010). In the troughs, partially resedimented Lower Jurassic marlstonelimestone sequences may reach a non-decompacted thickness of $3000 \mathrm{~m}$ (e.g. in the Generoso Trough), but condensation and hiatuses characterize the paleohigh sections with reddish nodular facies. Along slopes connecting structural highs to the troughs, sedimentation was marked by slumps, resedimented bodies, and, locally, megabreccias within condensed and occasionally incomplete facies (Gaetani and Erba, 1990; Gaetani, 2010) (Fig. 1). In addition to regional tectonics, the Lombardy Basin successions record global climatic and oceanographic changes, including the T-OAE (Erba et al., 2019). In fact, lower Toarcian black shales have been documented in various sections, offering the opportunity to investigate the consequences of the T-OAE global changes on marine biota in the Tethys Ocean (Erba et al., 2019).

After close investigations of section outcropping in the Lombardy Basin, the Colle di Sogno and Gajum sites were selected as the most promising locations for continuous coring of pelagic records (Gaetani and Erba, 1990; Casellato and Erba, 2015) for continuous coring. In this paper, we document coring operations and lithostratigraphic characterization of both the Sogno and Gajum cores and outline ongoing multidisciplinary research.

\section{Coring through the sedimentary record of the early Toarcian Oceanic Anoxic Event}

The T-OAE is considered a natural Earth system experiment, which allows us to (a) detect and quantify processes associated with emissions of greenhouse gases and natural atmospheric pollutants; (b) understand the role of greenhouse gases on climate dynamics and its influence on the hydrological cycle; (c) characterize changes in ocean and atmospheric chemistry and their interactions; (d) assess changes in biodiversity and dynamics of ecosystems and understand the functioning of biotic sinks; and (e) quantify biosphere-geosphere-atmosphere interactions and their timings or rates.

Analysis of past global change requires the collection of high-resolution data from continuous and ideally unweathered sequences. In surface outcrops, sedimentary rocks and particularly black shales are commonly badly degraded and, consequently, drilling is crucial to ensure the recovery of high-quality fresh cored material. In this paper we identify the T-OAE adopting the original definition by Jenkyns (1985) based on lithostratigraphy. Therefore, the T-OAE in the Lombardy Basin corresponds to the Livello a Pesci (Tintori, 1977; Gaetani and Poliani, 1978; Erba and Casellato, 2010; Erba et al., 2019). This interval has an average thickness of 0.5 to $5 \mathrm{~m}$, but reaches a few tens of metres in the most expanded sections. Black shales are rarely recorded on paleohighs, whereas they are ubiquitous in deeper basins. As the TOAE occurred at a global scale, the local lack of black shales 

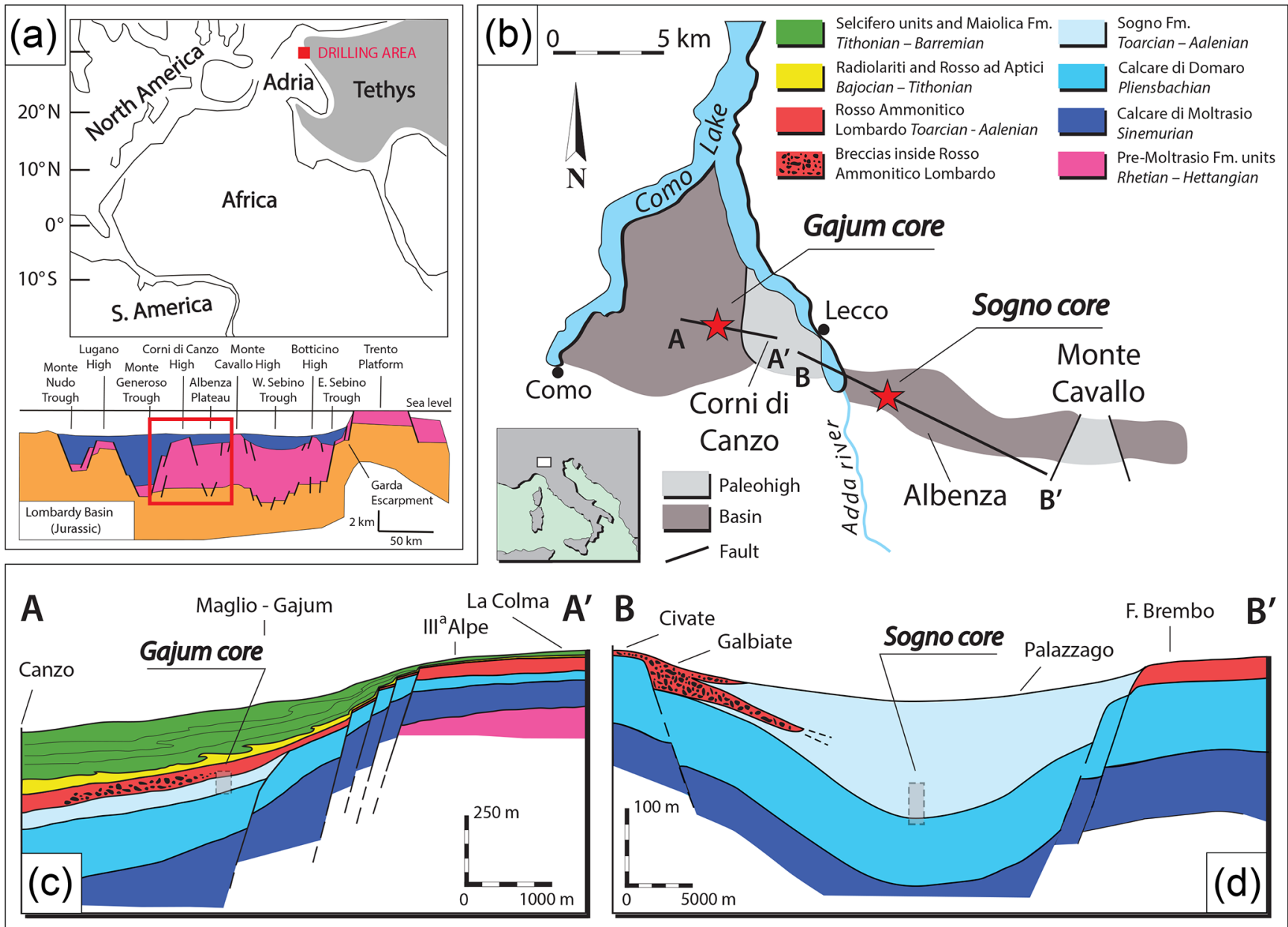

Figure 1. Location of the Sogno and Gajum drilling sites relative to (a) paleogeography and (b) current geography. The drilling area was part of the Lombardy Basin (Southern Alps). (c) The Gajum core is sited in an inner basin along the western slope of the Corni di Canzo High while (d) the Sogno core was drilled on the Albenza Plateau as detailed in the geological sections in the lower part of the figure (modified after Gaetani and Poliani, 1978 and Gaetani and Erba, 1990).

in the Lombardy Basin is usually the result of condensation and/or stratigraphic gaps.

\section{Location of the drill sites and justification for coring}

Two Lower Jurassic sections at Colle di Sogno and Gajum, respectively, were selected for continuous coring through the Toarcian organic-rich black shale interval (Fig. 1). Within the Lombardy Basin, these sections represent significantly different geological settings on a pelagic structural high, namely the Albenza Plateau (Colle di Sogno) and in an inner basin along the slope of the Mt Corni di Canzo structural high (Gajum) (Gaetani and Erba, 1990; Gaetani, 2010). Both successions are relatively expanded and lack the diagenetic manganese-carbonate horizons (present in the Toarcian black shales of the Belluno Basin, Southern Alps, for example) that would compromise primary geochemical signatures
(Farrimond et al., 1988; Jenkyns, 1988; Jenkyns et al., 1991; Bellanca et al., 1999).

The Colle di Sogno site (Fig. 1) was selected because the Jurassic sequence exposed is pelagic, stratigraphically continuous and relatively expanded (Gaetani and Erba, 1990; Muttoni et al., 2005; Channell et al., 2010; Casellato and Erba, 2015). It consists of limestone and marlstone, with chert and marly claystone as minor lithologies. The T-OAE is here represented by $\sim 5 \mathrm{~m}$ of dark grey to black marly claystones of the Livello a Pesci. At Colle di Sogno, the type-section of the Sogno Formation (Gaetani and Poliani, 1978), located along the road SP 179 on the northern slope of Mt Brughetto, was proved to be suitable for high-resolution multidisciplinary studies of litho-, bio-, chemo-, magneto-, and cyclo-stratigraphy (Gaetani and Poliani, 1978; Jenkyns and Clayton, 1986; Gaetani and Erba, 1990; Hinnov et al., 2000; Channell et al., 2010; Casellato and Erba, 2015). 
The Gajum succession crops out in a small lateral cut of the Ravella valley (Fig. 1), where the basal lithofacies of the Moltrasio Limestone Formation suggests sedimentation in shallower water than on the Albenza Plateau (Gaetani and Poliani, 1978; Gaetani and Erba, 1990; Pasquini and Vercesi, 2002). In particular, slumps and resedimented bodies with an eastward-sliding direction document a constant instability of the ramp, indicating that the succession developed in a small inner basin separated by a sill from a deeper basin to the west (Pasquini and Vercesi, 2002). A sharp lithological change marks the boundary between the carbonaterich lithologies of the Domaro Limestone Formation and the overlying clay-rich lithologies of the lower Sogno Formation consisting of marlstones and marly limestones followed by reddish nodular limestones of the Rosso Ammonitico Lombardo. At Gajum the expanded nature of the black shale interval $(\sim 15 \mathrm{~m})$ offers the opportunity for studying the inception, evolution, and termination of the T-OAE in great detail.

\section{Drilling operations and lab core preparation}

The Sogno drilling campaign took place in June 2013, while the Gajum core was drilled in February 2016 (Fig. 2). At both Sogno and Gajum sites, drilling operations were performed with the DELTABASE 520 Modular Hydraulic Rotary Drill. The Sogno coring was accomplished with a T2 double corer, using narrow-kerf, sawtoothed drill bits that cut a $101 \mathrm{~mm}$ diameter borehole and $84 \mathrm{~mm}$ diameter cores. The Gajum core was obtained using a modified T6 triplex corer, including a plastic liner for the best recovery, using narrow-kerf, sawtoothed drill bits that cut a $131 \mathrm{~mm}$ diameter borehole and $101 \mathrm{~mm}$ diameter cores. At Gajum, after coring, the borehole was logged using a QL40-OBI optical televiewer to obtain high-resolution images of the borehole wall, together with a total gamma radiation tool (Fig. 3).

All cores were initially described on site and a preliminary log was produced. Then, cores were packed, labelled, and put in PVC plastic boxes to prevent contamination and transported to the Department of Earth Sciences in Milan where they are archived. Here, during lab preparation, all cores were longitudinally split along the dip and divided into an archive half and a sampling half, both marked at centimetre scale. The archive half was photographed in high resolution and composite photologs were produced for each site.

\section{Preliminary results}

\subsection{Lithostratigraphy of the Sogno core}

Four distinct boreholes (S1, S2, S3, and S4) were drilled at Colle di Sogno along the SP 179 road $\left(45^{\circ} 47^{\prime} 20.5^{\prime \prime} \mathrm{N}\right.$, $\left.9^{\circ} 28^{\prime} 30.0^{\prime \prime} \mathrm{E}\right)$. The outcropping beds show a strike of $150^{\circ}$ and a dip of $68^{\circ}$ to the southwest $\left(240^{\circ}\right)$.

Initially, a single borehole was planned to penetrate the lower Toarcian-uppermost Pliensbachian interval and reach the base of the Sogno Formation at $\sim 35 \mathrm{~m}$ penetration depth However, at $\sim 25 \mathrm{~m}$ penetration depth (core S1-27) a sharp dip increase to $88^{\circ}$ revealed the occurrence of a fold, partially faulted and reversed, persisting for $\sim 4 \mathrm{~m}$ (cores S1-27, S128 , and S1-29). Indeed, core S1-30 perfectly correlates with the lower part of core S1-26 and two black shales were used as lithostratigraphic markers. Coring was extended for $\sim 2 \mathrm{~m}$ (cores S1-31 and S1-32) penetrating the top of the black shale interval and then operations were interrupted to shift drilling to borehole S2 (Fig. 4). Due to the steep dip, it was decided to perform a $10^{\circ}$ inclined coring to decrease the total penetration depth down into the Domaro Limestone Formation. Borehole S2 started just above the top of the black shale interval of the Livello a Pesci, perfectly duplicating core S1-32. However, technical problems prevented coring below a few metres and operations stopped after recovery of core S2-3. The third borehole (S3) was moved $0.5 \mathrm{~m}$ relative to $\mathrm{S} 2$ and was cored vertically. Again, the recovered succession started from just above the top of the black shale interval with core S3-1 triplicating cores S1-32 and S2-1. Coring was extended to $40 \mathrm{~m}$ penetration depth, reaching the uppermost part of the Domaro Limestone Formation (Fig. 4). A fourth borehole (S4) was performed to duplicate the middle and lower portion of the black shale interval to ensure material for multidisciplinary investigations. The recovery percentage for the four boreholes is $99.9 \%$.

Lithostratigraphic units were defined on the basis of lithological features (i.e. lithology and colours determined with the Munsell Rock Color Chart) and sedimentary structures (i.e. presence or lack of bioturbation and/or lamination). For each core at least four dip measurements were taken during lab preparation to calculate the stratigraphic thickness of the drilled section as $25.33 \mathrm{~m}$ under $1.5 \mathrm{~m}$ of rubble at the top. A complete composite section, representing the upper Pliensbachian-lower Toarcian interval, was created by combining the data obtained from the S1 and S3 boreholes (Fig. 5). The following key observations were derived:

1. The first $1.5 \mathrm{~m}$ of the $\mathrm{S} 1$ borehole are represented by soil cover and rubble.

2. The S1 core, despite the occurrence of a faulted fold disturbing the succession, recovered a complete section above the Livello a Pesci. The bottommost part of the well reached the uppermost part of the black shale interval. This correlates with the top black shale interval recovered in the upper part of the $\mathrm{S} 3$ core.

3. The upper limit of the black shale interval was cored both at $\mathrm{S} 1$ and $\mathrm{S} 3$ sites.

4. The S3 core recovered a few metres of succession above the black shale interval, the entire Livello a Pesci, and the lower portion of the Sogno Formation, in addition to the topmost part of the Domaro Limestone. In particular, at $25.47 \mathrm{~m}$, the lithostratigraphic boundary between 

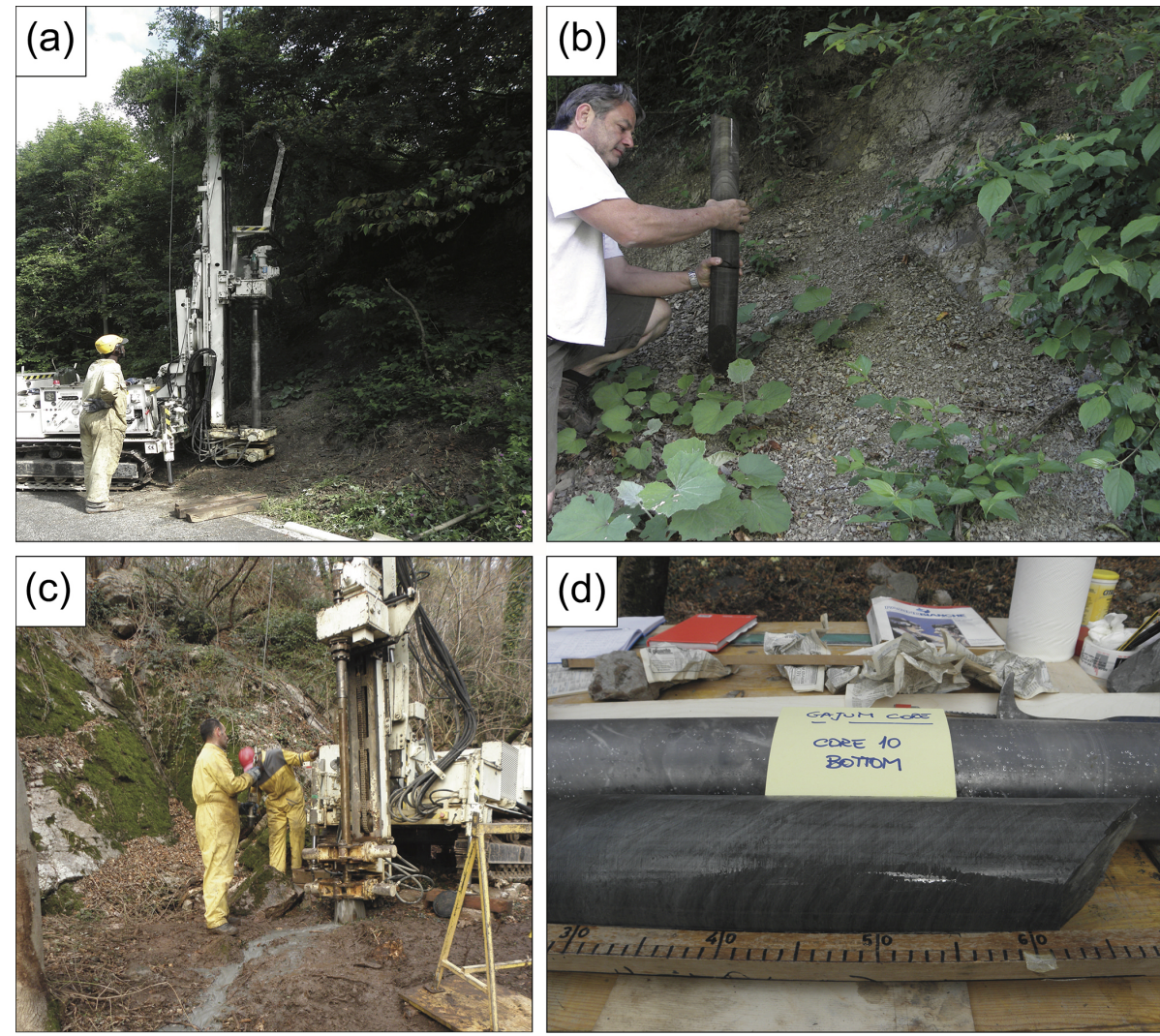

Figure 2. Coring operations and results at Sogno and Gajum sites. (a) Coring Sogno Site 4. (b) Livello a Pesci in the Sogno core compared to the equivalent outcropping lithostratigraphic interval. (c) Coring at Gajum. (d) Black shale interval recovered in core 10 of the Gajum core.

the Sogno Formation and Domaro Limestone Formation was recovered.

Combining the above information and considering the dip measured in individual cores (variable in the range of 60 to $87^{\circ}$ ), the "stratigraphic thickness" of each lithostratigraphic unit was calculated. The overlapping intervals (i.e. U1-5 and U3-1) were matched and duplications were eliminated. The lithologic log of the composite S1-S3 Sogno core, in stratigraphic depths (from 1.5 to $26.83 \mathrm{~m}$ ), is illustrated in Fig. 5 . The composite S1-S3 Sogno core section recovered a complete upper Pliensbachian-lower Toarcian interval, with the S1 core representing its upper portion, and the S3 core the lower part.

The following lithostratigraphic units (U1-1 to U1-5, and U3-2 to U3-11, of the S1 and S3 cores, respectively) are described, from the topmost to the bottommost:

- Unit 1 (1.50 to $4.82 \mathrm{~m}$ ): marly limestones, olive-grey in colour. In the upper and lowermost parts of the unit, high concentrations of reddish mottles and sporadic bioturbation are documented.

- Unit 2 (4.82 to 9.54 m): marly limestones, olive-grey in colour, characterized by intense bioturbation. In partic- ular, the uppermost part of the unit documents the presence of frequent Planolites.

- Unit 3 (9.54 to $10.52 \mathrm{~m}$ ): marly limestones, grey in colour, characterized by intense bioturbation. Locally, faintly laminated intervals are observed.

- Unit 4(10.52 to 11.87 m): marly limestones with evident and widespread bioturbation. Locally, 1 to $6 \mathrm{~cm}$ thick black shales and laminated intervals are present.

- Unit 5 (11.87 to $14.55 \mathrm{~m}$ ): black shales characterized by well-developed lamination, especially in the uppermost part, in addition to pyrite nodules. In the lower portion, very little bioturbation is documented.

- Unit 6(14.55 to $15.93 \mathrm{~m})$ : marly limestones, grey to very dark-grey in colour, with reddish to greyish spots. Bioturbation (burrow) dimensions increase within this unit and thin emerald-green laminae are documented.

- Unit 7 (15.93 to $16.86 \mathrm{~m}$ ): marly limestones, with variations in colour from grey, to very dark-grey and darkred. In the lowermost portion, bioturbation and lamination are observed. 


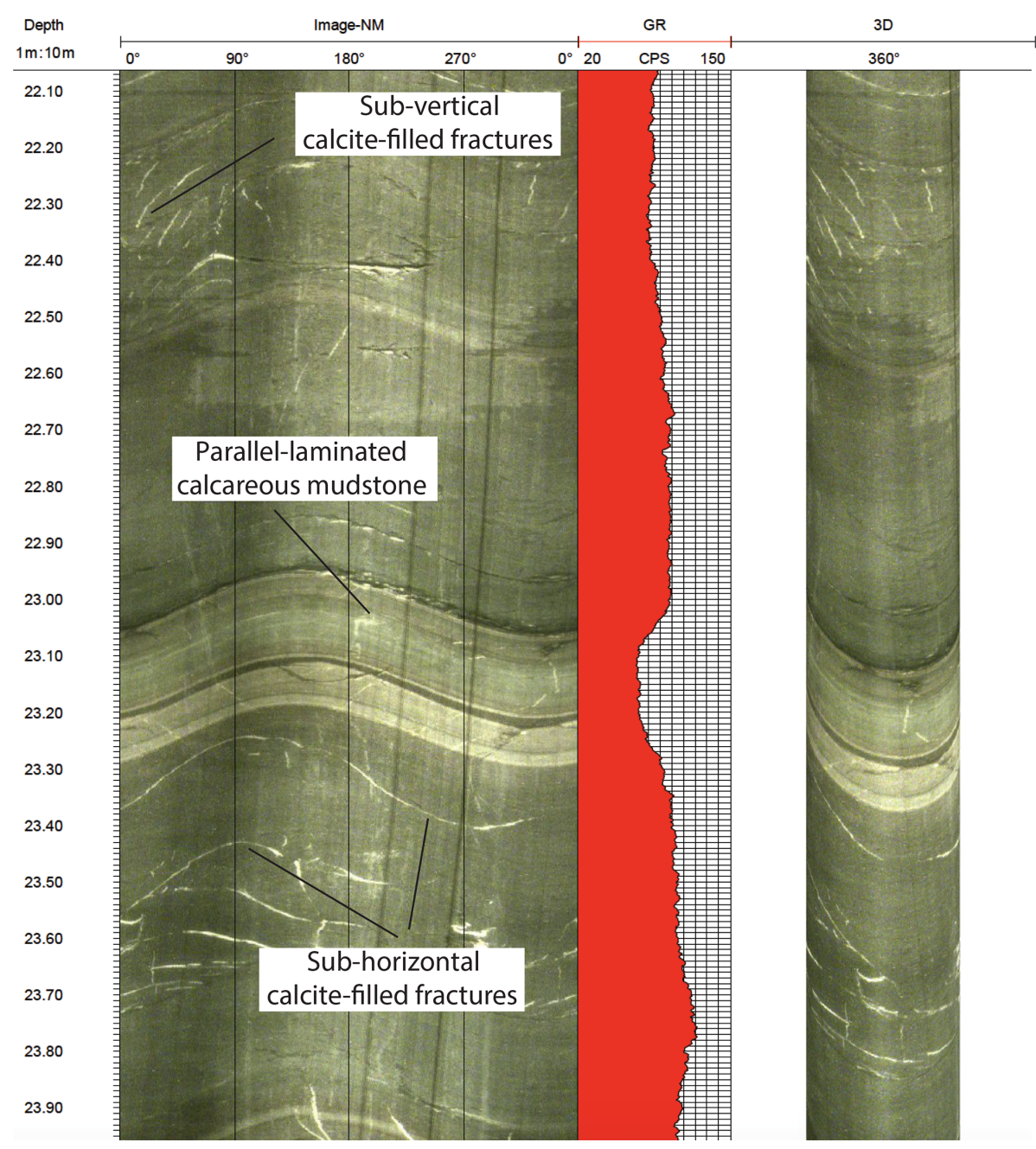

Figure 3. Example of Gajum borehole wall image recorded with a QL40-OBI optical televiewer. From left to right: borehole depth, $360^{\circ}$ continuous upwrapped digital image of the borehole wall, total natural gamma ray, 3-D log visualization reproducing a virtual core of the borehole.

- Unit 8 (16.86 to 19.10 m): marly limestones, dark-red in colour, with sporadic greyish spots.

- Unit 9 (19.10 to 19.45 m): marly limestones, grey in colour.

- Unit 10 (19.45 to 21.35 m): marly limestones, greybrown in colour. This is a disturbed interval comprising a level of pebbly marlstones (between 19.45 and $20.03 \mathrm{~m}$ ), with minor slump structures. Sporadic stylolites are present.

- Unit 11 (21.35 to 22.92 m): marly limestones, grey in colour, characterized by frequent stylolite structures. In addition, $2 \mathrm{~cm}$ thick black shale intervals are documented at $\sim 21.8$ and $22 \mathrm{~m}$, respectively.

- Unit 12 (22.92 to 24.35 m): marly limestones, alternating in colour from reddish to olive-grey. Sporadic bioturbation and lamination can be observed.
- Unit 13 (24.35 to 24.99 m): marly limestones, reddishgreyish in colour.

Unit 14 (24.99 to $25.47 \mathrm{~m})$ : marly limestones, lightbrown to grey-brown in colour. Small and large $(1 \mathrm{~cm}$ thick) burrows are documented. The base of this unit corresponds to the base of the Sogno Formation.

- Unit 15 (25.47 to 26.83 m): marly limestones, olive-grey to dark-grey in colour. Small bioturbations and frequent stylolite structures are observed. This unit corresponds to the uppermost part of the Domaro Limestone Formation.

\subsection{Lithostratigraphy of the Gajum core}

The Gajum core $\left(45^{\circ} 51^{\prime} 03.2^{\prime \prime} \mathrm{N}, 09^{\circ} 17^{\prime} 19.5^{\prime \prime} \mathrm{E}\right.$, at $555 \mathrm{~m}$ above sea level) was drilled close to "Fonte Gajum" - Canzo (CO), in the Ravella valley next to the trail named Via delle 


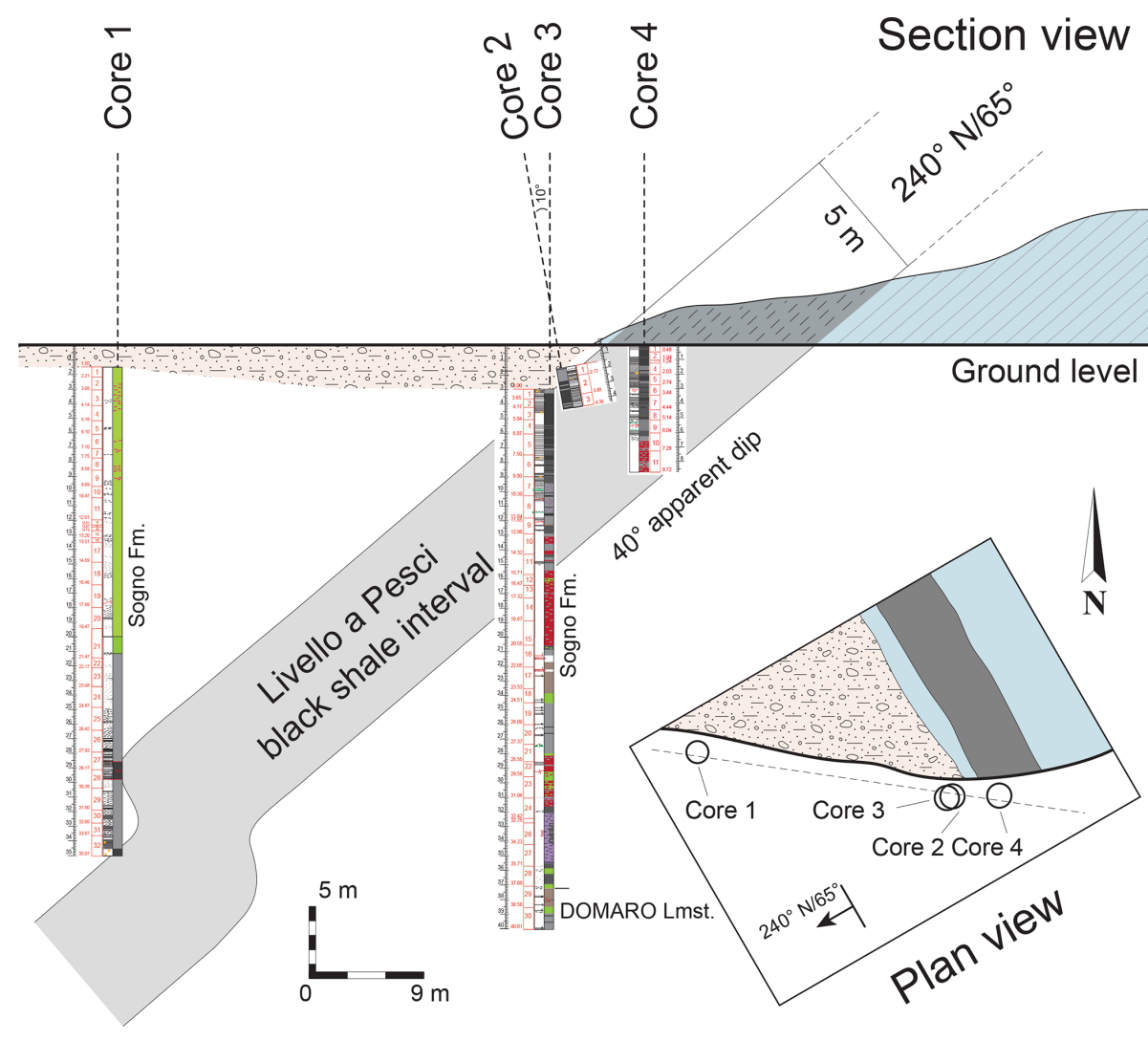

Figure 4. Section and plan view of the relative positions of the four boreholes drilled at Colle di Sogno. A pronounced fold was encountered at $\sim 25 \mathrm{~m}$ penetration depth in Sogno borehole 1 that was abandoned after reaching the topmost part of the black shale interval. Three additional boreholes were cored as explained in the text.

Alpi (Fig. 1). The outcropping beds show a strike of $245^{\circ}$ and a dip of $46^{\circ}$ to the northwest $\left(335^{\circ}\right)$.

A single borehole was drilled at Gajum to a total penetration depth of $42.37 \mathrm{~m}$, with $100 \%$ recovery of excellentquality material throughout drilling operation. For each core a set of dip measurements was taken during lab preparation, with four measurements on average, and used to calculate the corrected thickness of the drilled section as $28.18 \mathrm{~m}$ after removal of $3 \mathrm{~m}$ of rubble at the top. As for the Sogno core, lithostratigraphic units were defined based on lithological features and sedimentary structures. The dip measured in individual cores (variable in the range of 40 to $50^{\circ}$ ) was used to calculate the "stratigraphic thickness" of each lithostratigraphic unit described below, from the topmost to the bottommost:

- Unit 1 (3.00 to $4.35 \mathrm{~m}$ ): dark brown to dusky red nodular limestone. nodules are $3-5 \mathrm{~cm}$ in size and light grey in colour. A resedimented level, consisting of a microbreccia, is detected at $3.92-3.96 \mathrm{~m}$. This unit corresponds to the lower part of the Rosso Ammonitico Lombardo.

- Unit 2 (4.35 to $7.60 \mathrm{~m}$ ): marly limestone, grey to olive grey in colour, with dark grey laminated intervals. Three black shale intervals occur at 5.24-5.35, 6.26-6.43, and $6.70-6.81 \mathrm{~m}$.

- Unit 3 (7.60 to $10.60 \mathrm{~m}$ ): grey to dark grey marly limestone, with heavily bioturbated levels alternating with intervals characterized by faint lamination. Some pyrite nodules are observed in the lowermost part of the unit.

- Unit 4 (10.60 to $21.39 \mathrm{~m})$ : dark to very dark grey to black marly claystones. This "black shale" interval is characterized by well-developed lamination and frequent pyrite nodules. In the upper and middle portion, discrete intervals with faint bioturbation are observed.

- Unit 5 (21.39 to $25.42 \mathrm{~m})$ : dark to very dark grey to black marly claystones characterized by well-developed lamination and a few pyrite nodules. Three intervals of dusky red limy cherts are identified at 21.39-21.87, 23.52-23.81, and $24.30-25.52 \mathrm{~m}$. The highest and lowest cherty reddish levels delimit the top and bottom of this unit, respectively.

- Unit 6 (25.42 to $26.95 \mathrm{~m})$ : dark grey to very dark grey to black marly claystones, with evident laminations and sporadic faint bioturbations. The base is undulated. 
(a)

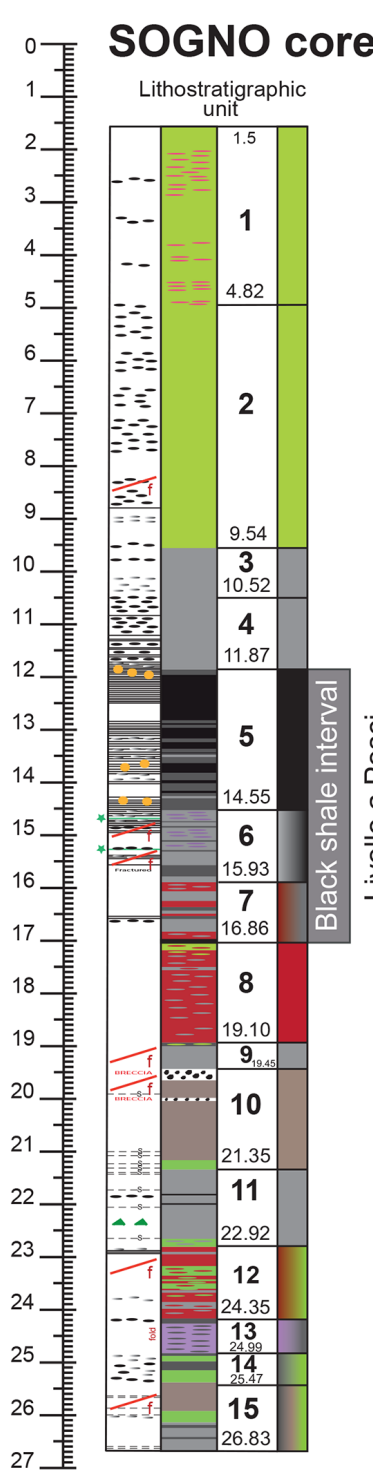

(b) GAJUM core

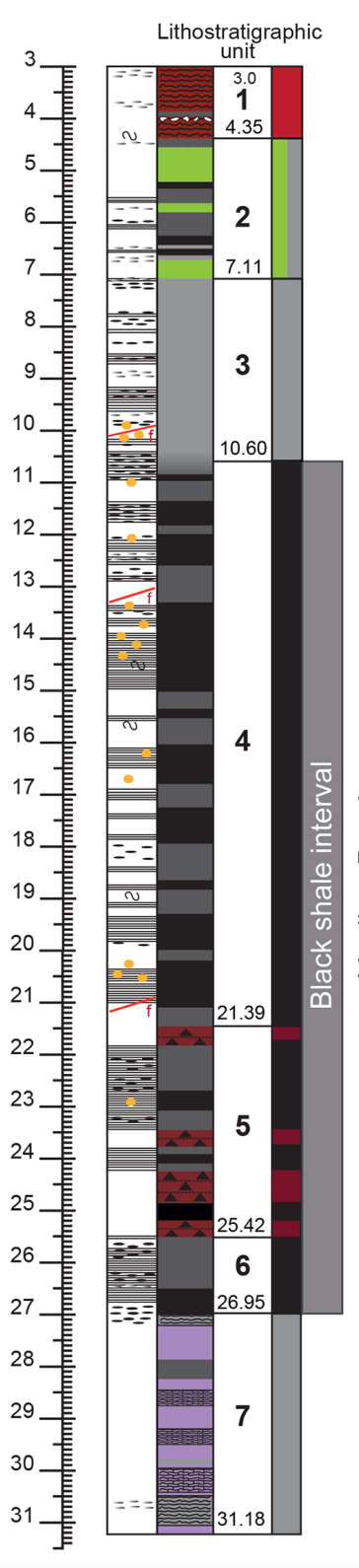

$\mathrm{CaCO}_{3}(\%)$

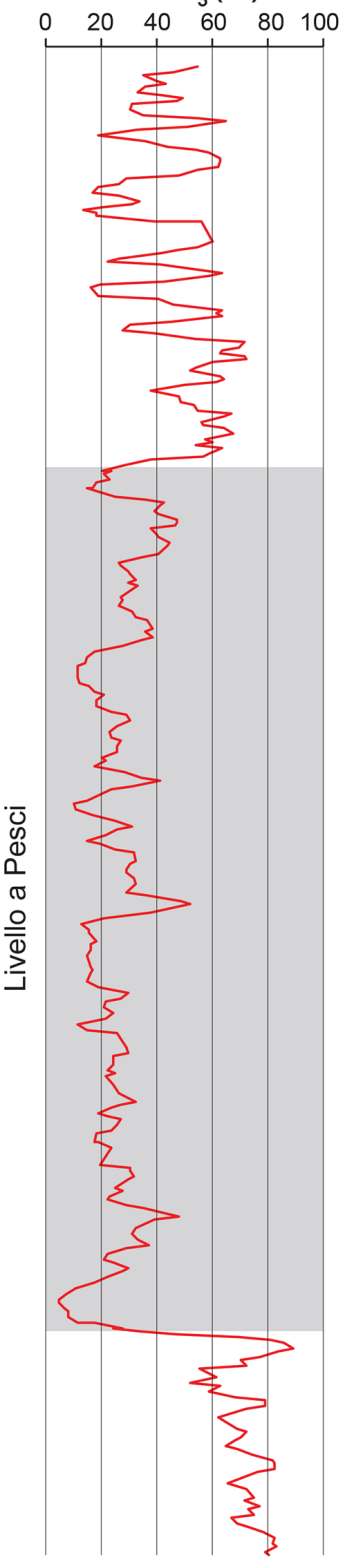

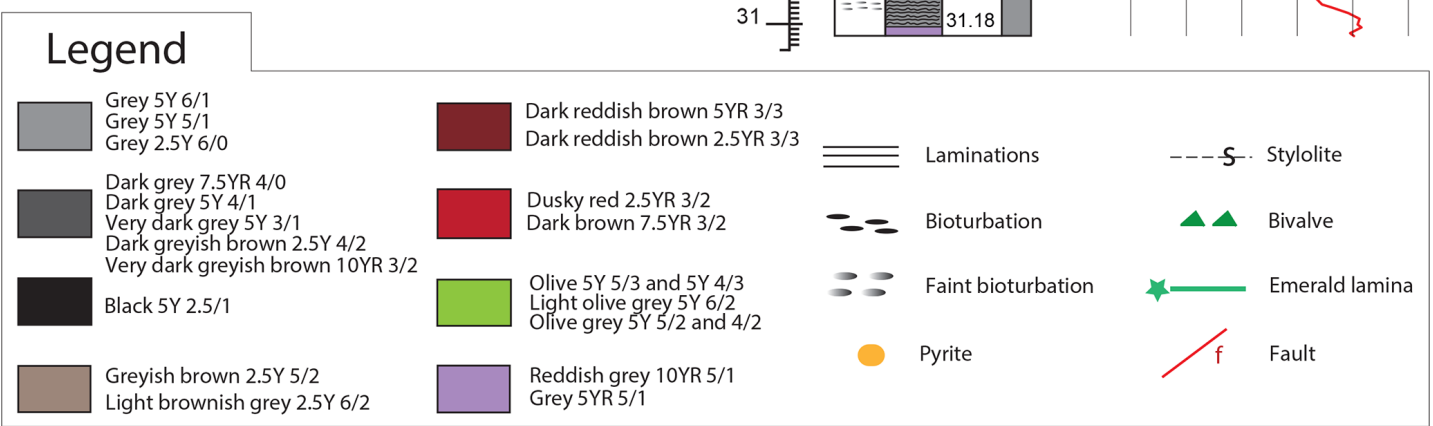

Figure 5. Lithostratigraphy and calcium carbonate content of the Sogno (a) and Gajum (b) cores. The grey pattern highlights the Livello a Pesci black shale interval that is the lithostratigraphic record of the T-OAE in the Lombardy Basin. The $\mathrm{CaCO}_{3}$ content was detected using the Dietrich-Frühling gas volumetric method by measuring evolved $\mathrm{CO}_{2}$ after acidification of the bulk sample with $\mathrm{HCl}$. 
- Unit 7 (26.95 to $31.18 \mathrm{~m})$ : grey to reddish grey marly limestones, with fractures filled by diagenetic calcite.

In Fig. 5 the Sogno and Gajum cores are correlated: the TOAE black shale interval is represented in both sections, but with significantly different thicknesses, namely $4.98 \mathrm{~m}$ in the Sogno core and $15.35 \mathrm{~m}$ in the Gajum core. The lithostratigraphic onset and termination of the Livello a Pesci black shale interval, based on the lowest and highest black marly claystones, are nicely preserved in both cores, without lithologic evidence of hiatus or disturbance. In the Gajum core the beginning of the anoxic interval is quite abrupt and represented by the change from a few centimetres thick, grey, pseudonodular, and heavily bioturbated marly limestone to black shales with an irregular base mimicking nodularity of the underlying interval: this lithostratigraphic boundary is very similar to the onset of the early Aptian OAE1a in the Cismon core (Erba et al., 2010; Fig. 2). The upper boundary is, conversely, relatively transitional from laminated black shales to dark grey marly limestones. In the Sogno core, instead, both the base and top of the black shale interval are sharp.

The Livello a Pesci is not homogeneous in the Sogno and Gajum cores: in both records, the lower part is characterized by the occurrence of a few reddish levels. These are cherty in the Gajum core (Unit 5) and clayey in the Sogno core (Unit 7). Also, black shales are dominant in the upper part of the Livello a Pesci in both cores (Unit 4 of the Gajum core and Unit 5 of the Sogno core).

As far as the calcium carbonate content is concerned (Fig. 5) in the Sogno and Gajum cores, the interval below the Livello a Pesci is characterized by values of around $60 \%$ and $60 \%-80 \% \mathrm{CaCO}_{3}$, respectively. A drop in calcium carbonate content to an average of $20 \%$ is recorded within the black shale interval in both cores, with lowermost values of $5 \%$ (Gajum core) to $10 \%$ (Sogno core) in the lowermost part. Above the Livello a Pesci, the calcium carbonate content reverts to $40 \%-60 \%$, with frequent fluctuations.

\section{Future objectives}

The fresh material recovered with the Sogno and Gajum cores provide complete and relatively expanded pelagic records from the western Tethys Ocean. Detailed multidisciplinary investigations are in progress to collect multi-proxy records for building a high-resolution dataset prodromic for modelling the nature and significance of the T-OAE. The specific objectives are as follows:

1. High-resolution integrated stratigraphy. This is based on nannofossil biostratigraphy, magnetostratigraphy, chemostratigraphy, and cyclostratigraphy. Milankovitch cycles will be used to estimate durations of the T-OAE.

2. Detailed studies of critical paleoceanographic parameters. This includes total organic carbon; isotopic anoma- lies; and major, minor and trace elements that will be used to assess changes in surface and bottom water mass characteristics.

3. Identification and quantification of the response of the biosphere. This is based on quantitative and highresolution investigation of calcareous phytoplankton assemblages. In particular, we will focus on the relative timing and possible phase-lag of the response to the overwhelming forcing function/s. These relationships will be used to model the resilience of the oceanic biosphere.

4. Characterization of the Early Jurassic climate, ocean dynamics, and their response to orbital cyclicity.. In particular, we plan to decipher local from regional and global changes across the paleoenvironmental perturbation. Also, the cyclostratigraphy will allow for the assessment of the influence of eccentricity, obliquity, and precession cycles before, during, and after the T-OAE.

Data availability. The Sogno and Gajum cores are stored at the Department of Earth Sciences "Ardito Desio" of the University of Milan (Italy). Data are publicly accessible upon request.

Author contributions. EE conceived and executed the Sogno and Gajum coring. She coordinated the lab core work and prepared the paper. GG co-supervised the core description and contributed to the paper. Other co-authors ( $\mathrm{SV}, \mathrm{LC}, \mathrm{DR}, \mathrm{GF}, \mathrm{MP}$ ) contributed to core splitting, archiving, and sampling.

Competing interests. The authors declare that they have no conflict of interest.

Acknowledgements. The T-OAE coring project derived from fieldwork and in-depth discussions with Maurizio Gaetani on Jurassic stratigraphy of the Lombardy Basin. We acknowledge the editor Thomas Wiersberg, and the two reviewers Alicia Fantasia and Stephen Hesselbo, who greatly improved the quality of the paper with their constructive comments.

Financial support. This research has been supported by the MIUR (MIUR-PRIN2011 grant no. 2010X3PP8J) awarded to Elisabetta Erba.

Review statement. This paper was edited by Thomas Wiersberg and reviewed by Stephen Hesselbo and Alicia Fantasia. 


\section{References}

Al-Suwaidi A. H., Angelozzi, G. N., Baudin F., Damborenea, S. E., Hesselbo, S. P., Jenkyns, H. C., Manceñido M. O., and Riccardi A. C.: First record of the Early Toarcian Oceanic Anoxic Event from the Southern Hemisphere, Neuquén Basin, Argentina, J. Geol. Soc. London, 167, 633-636, 2010.

Bellanca, A., Masetti, D., Neri, R., and Venezia, F.: Geochemical and sedimentological evidence of productivity cycles recorded in Toarcian black shales from the Belluno Basin, Southern Alps, northern Italy, J. Sediment. Res., 69B, 466-476, 1999.

Bernoulli, D. and Jenkyns, H. C.: Alpine, Mediterranean, and Central Atlantic Mesozoic facies in relation to the early evolution of the Tethys, in: Modern and Ancient Geosynclinal Sedimentation, edited by: Dott, R. H. and Shaver R. H., Soc. Econ. Paleont. Mineral., Spec. Publ., 19, 129-160, 1974.

Bernoulli, D. and Jenkyns, H. C.: Ancient oceans and continental margins of the Alpine-Mediterranean Tethys: Deciphering clues from Mesozoic pelagic sediments and ophiolites, Sedimentology, 56, 149-190, 2009.

Bosence, D., Procter, E., Aurell, M., Kahla, A. B., BoudagherFadel, M., Casaglia, F., Cirilli, S., Mehdie, M., Nieto, L., Rey, J., Scherreiks, R., Soussi, M., and Waltham, D.: A Dominant Tectonic Signal in High-Frequency, Peritidal Carbonate Cycles? A Regional Analysis of Liassic Platforms from Western Tethys, J. Sedimet. Res., 79, 389-415, 2009.

Caruthers, A. H., Gröcke, D. R., and Smith, P. L.: The significance of an Early Jurassic (Toarcian) carbon-isotope excursion in Haida Gwaii (Queen Charlotte Islands), British Columbia, Canada, Earth Planet. Sc. Lett., 307, 19-26, 2011.

Casellato, C. E. and Erba, E.: Calcareous nannofossil biostratigraphy and paleoceanography of the Toarcian Oceanic Anoxic Event at Colle di Sogno section (Southern Alps, Italy), Riv. Ital. Paleontol. S., 105, 343-376, 2015.

Channell, J. E. T., Casellato, C. E., Muttoni, G., and Erba, E.: Magnetostratigraphy, nannofossil stratigraphy and apparent polar wander for Adria-Africa in the Jurassic-Cretaceous boundary interval, Palaeogeogr. Palaeocl., 293, 51-75, 2010.

Cohen, A. S., Coe, A. L., Harding, S. M., and Schwark, L.: Osmium isotope evidence for the regulation of atmospheric $\mathrm{CO}_{2}$ by continental weathering, Geology, 32, 157-160, 2004.

Dera, G., Brigaud, B., Monna, F., Laffont, R., Pucéat, E., Deconinck, J.-F., Pellenard, P., Joachimski, M. M., and Durlet, C.: Climatic ups and downs in a disturbed Jurassic world, Geology, 39, 215-218, 2011.

Emmanuel, L., Renard, M., Cubaynes, R., De Rafelis, M., Hermoso, M., Lecallonnec, L., Le Solleuz, A., and Rey, J.: The "Schistes Carton" of Quercy (Tarn, France): a lithological signature of a methane hydrate dissociation event in the early Toarcian. Implications for correlations between Boreal and Tethyan realms, Bull. Soc. Géol. Fr., 177, 239-249, 2006.

Erba, E.: Calcareous nannofossils and Mesozoic oceanic anoxic events, Mar. Micropaleontol., 52, 85-106, 2004.

Erba, E. and Casellato C. E.: Paleoceanografia del Giurassico nella Tetide occidentale: l'archivio geologico del Bacino Lombardo, Rendiconti dell'Istituto Lombardo, Accademia di Scienze e Lettere, Special Publication on "Una nuova Geologia per la Lombardia”, 447, 115-140, 2010.
Erba, E., Bottini, C., Weissert, H. J., and Keller, C. E.: Calcareous nannoplankton response to surface-water acidification around Oceanic Anoxic Event 1a, Science, 329, 428-432, 2010.

Erba, E., Bottini, C., Faucher, G., Gambacorta, G., and Visentin, S.: The response of calcareous nannoplankton to Oceanic Anoxic Events: The Italian pelagic record, B. Soc. Paleontol. Ital., 58, 51-71, 2019.

Fantasia, A., Föllmi, K. B., Adatte, T., Bernaìrdez, E., Spangenberg, J. E., and Mattioli, E.: The Toarcian Oceanic Anoxic Event in southwestern Gondwana: an example from the Andean Basin, northern Chile, J. Geol. Soc., 175, 883-902, 2018.

Farrimond, P., Englinton, G., Brassell, S. C., and Jenkyns, H. C.: The Toarcian black shale event in northern Italy, Org. Geochem., 13, 823-832, 1988.

Gaetani, M.: Jurassic stratigraphy of the Southern Alps: a review, Geology of Italy, 1, 377-402, 1975.

Gaetani, M.: From Permian to Cretaceous: Adria as pivotal between extensions and rotations of Tethys and Atlantic Oceans, in: The Geology of Italy, edited by: Beltrando, M., Peccerillo, A., Mattei, M., Conticelli, S., and Doglioni, C., J. Virt. Expl., 36, paper 5.a, https://doi.org/10.3809/jvirtex.2010.00235, 2010.

Gaetani, M. and Erba, E.: Il bacino Lombardo: un sistema paleoalto/fossa in un margine continentale passivo durante il Giurassico, $75^{\circ}$ Congresso Soc. Geol. It., 10-12 September 1990, Milano, Italy, Guida all'escursione A3, 1990.

Gaetani, M. and Poliani, G.: Il Toarciano e il Giurassico medio in Albenza (Bergamo), Riv. Ital. Paleontol. S., 84, 349-382, 1978.

Gómez, J. J., Comas-Rengifo, M. J., and Goy, A.: Palaeoclimatic oscillations in the Pliensbachian (Early Jurassic) of the Asturian Basin (Northern Spain), Clim. Past, 12, 1199-1214, https://doi.org/10.5194/cp-12-1199-2016, 2016.

Hardenbol, J., Thierry, J., Farley, M. B., Jacquin, T., de Graciansky, P.-C., and Vail, P. R.: Mesozoic and Cenozoic sequence chronostratigraphic framework of European basins, in: Mesozoic and Cenozoic sequence stratigraphy of European basins, edited by: de Graciansky, P.-C., Hardenbol, J., Jacquin T., and Vail, P. R., SEPM Special Publication, 60, 3-13, charts 1-8, Tulsa, Oklahoma, 1998.

Haq, B. U., Hardenbol, J., and Vail, P. R.: Chronology of fluctuating sea-levels since the Triassic, Nature, 235, 1156-1167, 1987.

Hesselbo, S. P., Gröcke, D. R., Jenkyns, H. C., Bjerrum, C. J., Farrimond, P., Morgans Bell, H. S., and Green, O. R.: Massive dissociation of gas hydrate during a Jurassic Oceanic Anoxic Event, Nature, 406, 392-395, 2000.

Hesselbo, S. P., Jenkyns, H. C., Duarte, L. V., and Oliveira, L. C. V.: Carbon-isotope record of the Early Jurassic (Toarcian) Oceanic Anoxic Event from fossil wood and marine carbonate (Lusitanian Basin, Portugal), Earth Planet. Sc. Lett., 253, 455-470, 2007.

Hinnov, L. A. Park, J., and Erba E.: Lower-Middle Jurassic rhythmites from the Lombard Basin, Italy: a record of orbitally forced carbonate cycles modulated by secular environmental changes in West Tethys, in: Advances in Jurassic Research, edited by: Hall R. L. and Smith P. L., Trans Tech Publications, 437-454, Zurich, Switzerland, 2000.

Izumi, K., Miyaji, T., and Tanabe, K.: Early Toarcian (Early Jurassic) oceanic anoxic event recorded in the shelf deposits in the northwestern Panthalassa: evidence from the Nishinakayama for- 
mation in the Toyora area, west Japan, Palaeogeogr. Palaeocl., 315-316, 100-108, 2012.

Jenkyns, H. C.: The Early Toarcian and Cenomanian-Turonian anoxic events in Europe: comparisons and contrasts, Geol. Rundsch., 74, 505-518, 1985.

Jenkyns, H. C.: The Early Toarcian (Jurassic) Anoxic Event: stratigraphic, sedimentary and geochemical evidence, Am. J. Sci., 288, 101-151, 1988.

Jenkyns, H. C.: Geochemistry of oceanic anoxic events, Geochem. Geophy. Geosy., 11, Q03004, https://doi.org/10.1029/2009GC002788, 2010.

Jenkyns, H. C. and Clayton, C. J.: Black shales and carbon isotopes in pelagic sediments from the Tethyan Lower Jurassic, Sedimentology, 33, 87-106, 1986.

Jenkyns, H. C., Géczy, B., and Marshall, J. D.: Jurassic manganese carbonates of central Europe and the early Toarcian anoxic event, J. Geol., 99, 137-149, 1991.

Jenkyns, H. C., Jones, C. E., Gröcke, D. R., Hesselbo, S. P., and Parkinson, D. N.: Chemostratigraphy of the Jurassic System: applications, limitations and implications for palaeocenography, J. Geol. Soc., 159, 351-378, 2002.

Kafousia, N., Karakitsios, V., Mattioli, E., Kenjo, S., and Jenkyns H. C.: The Toarcian Oceanic Anoxic Event in the Ionian Zone, Greece, Palaeogeogr. Palaeocl., 393, 135-145, 2014.

Korte, C. and Hesselbo, S. P.: Shallow marine carbon and oxygen isotope and elemental records indicate icehouse-greenhouse cycles during the early Jurassic, Paleoceanography, 26, PA4219, https://doi.org/10.1029/2011PA002160, 2011.

Mattioli, E., Pittet, B., Bucefalo Palliani, R., Rohl, H.-J., SchmidRohl, A., and Morettini, E.: Phytoplankton evidence for timing and correlation of palaeoceanographical changes during the Early Toarcian oceanic anoxic event (Early Jurassic), J. Geol. Soc. London, 161, 685-693, 2004.

Muttoni, G., Erba, E., Kent, D. V., and Bachtadse, V.: Mesozoic Alpine facies deposition as a result of past latitudinal plate motion, Nature, 434, 59-63, 2005.

Pasquini, C. and Vercesi, P. L.: Tettonica sinsedimentaria e ricostruzione paleogeografica del margine occidentale dell'Alto dei Corni di Canzo nel Lias inferiore, Memorie della Società Geologica Italiana, 57, 107-114, 2002.

Percival, L. M. E., Cohen, A. S., Davies, M. K., Dickson, A. J., Hesselbo, S. P., Jenkyns, H. C., Leng, M. J., Mather, T. A., Storm, M. S., and $\mathrm{Xu}, \mathrm{W}$.: Osmium isotope evidence for two pulses of increased continental weathering linked to Early Jurassic volcanism and climate change, Geology, 44, 759-762, 2016.
Posenato, R., Bassi, D., Trecalli, A., and Parente, M.: Taphonomy and evolution of Lower Jurassic lithiotid bivalve accumulations in the Apennine Carbonate Platform (southern Italy), Palaeogeogr. Palaeocl., 489, 261-271, 2018.

Reolid, M.: Stable isotopes on foraminifera and ostracods for interpreting incidence of the Toarcian Oceanic Anoxic Event in Westernmost Tethys: role of water stagnation and productivity, Palaeogeogr. Palaeocl., 395, 77-91, 2014.

Santantonio, M. and Carminati, E.: The Jurassic rifting evolution of the Apennines and Southern Alps (Italy): Parallels and differences, Bull. Geol. Soc. Am., 124, 468-484, 2011.

Schouten, S., van Kaam-Peters, H. M. E., Rijpstra, W. I. C., Schoell, M., and Sinninghe Damsté, J. S.: Effects of an oceanic anoxic event on the stable carbon isotopic composition of early Toarcian carbon, Am. J. Sci., 300, 1-22, 2000.

Solomon, S., Plattner, G.-K., Knutti, R., and Friedlingstein, P.: Irreversible climate change due to carbon dioxide emissions, P. Natl. Acad. Sci. USA, 106, 1704-1709, 2009.

Them, T. R., Gill, B. C., Selby, D., Gröcke, D. R., Friedman, R. M., and Owens, J. D.: Evidence for rapid weathering response to climatic warming during the Toarcian Oceanic Anoxic Event, Sci. Rep., 7, 5003, https://doi.org/10.1038/s41598-017-05307-y, 2017.

Tintori, A.: Toarcian fishes from the Lombardy Basin, B. Soc. Paleontol. Ital., 16, 143-152, 1977.

Trecalli, A., Spangenberg, J., Adatte, T., Föllmi, K. B., and Parente, M.: Carbonate platform evidence of ocean acidification at the onset of the early Toarcian oceanic anoxic event, Earth Planet. Sc. Lett., 357-358, 214-225, 2012.

van Breugel, Y., Baas, M., Schouten, S., Mattioli, E., and Damsté, J. S. S.: Isorenieratane record in black shales from the Paris Basin, France: Constraints on recycling of respired $\mathrm{CO}_{2}$ as a mechanism for negative carbon isotope shifts during the Toarcian oceanic anoxic event, Paleoceanography, 21, PA4220, https://doi.org/10.1029/2006PA001305, 2006.

Xu, W., Ruhl, M., Jenkyns, H. C., Hesselbo, S. P., Riding, J. B., Selby, D., Naafs, B. D. A., Weijers, J. W. H., Pancost, R. D., Tegelaar, E., and Idiz, E.: Carbon sequestration in an expanded lake system during the Toarcian oceanic anoxic event, Nat. Geosci., 10, 129-134, 2017. 